\author{
Justyna Fafara \\ Uniwersytet Marii Curie-Skłodowskiej w Lublinie \\ justynafafara@gmail.com
}

\title{
OCZAMI DZIECKA, CZYLI PORÓWNANIE SZATY \\ GRAFICZNEJ WE WSPÓLCZESNYCH ELEMENTARZACH (POLSKIM I BULGARSKIM) DLA PIERWSZOKLASISTÓW
}

Sposób rozumienia i postrzegania świata przez człowieka kreuje się już od najmłodszych lat. Dlatego też tak istotna jest edukacja wczesnoszkolna. Pierwszym podręcznikiem, z którym dzieci mają styczność jest elementarz. Niniejszy artykuł stanowi część badań, które prowadzę w związku z przygotowaniem pracy licencjackiej. Podjęłam w niej próbę analizy porównawczej wybranego elementarza dla pierwszoklasistów polskiego i bułgarskiego, aby zbadać je na różnych płaszczyznach. Jedną z nich jest szata graficzna i na niej szczególnie chcę się skupić w tym artykule. Zajmę się omówieniem różnic i podobieństw, a także wykazaniem cech charakterystycznych dla poszczególnych elementarzy.

Do tej pory badania na temat zestawienia elementarza polskiego i bułgarskiego nie zostały przeprowadzone. W literaturze naukowej możemy znaleźć jednak liczne publikacje związane $\mathrm{z}$ analizą poszczególnych typów podręczników i ich elementów, zarówno w języku polskim, jaki i bułgarskim. Profesor Daniela Todorova Jordanova $w$ jednej ze swoich prac stwierdziła, iż analiza bułgarskich podręczników dla pierwszej klasy skupia się na celach dydaktycznych i metodach dla ich osiągnięć, a kwestie szaty graficznej i używanych dla przykładu imion nie przyciągają uwagi badaczy [Йорданова 2002]. Natomiast w strukturze i wyglądzie podręczników coraz większą rolę odgrywają ilustracje. Tradycyjne teksty przytłaczane są przez dużą ilość obrazków przyciągających uwagę dziecka [Zalewska 2013], coraz częściej pojawiają się również odwołania do technologii cyfrowych. Na niektórych grafikach przedstawiających pomieszczenia pojawiają się różnego rodzaju sprzęty. Autorki artykułu Cyfrowy świat w podręczniku dla klasy pierwszej szkoły podstawowej-analiza treści zauważyły, iż rola dzieci w świecie technologii pokazywanym na ilustracjach została zdegradowana jedynie do pozycji obserwatorów [Adrjan, Kalinowska 2018]. Widać to szczególnie w elementarzu polskim.

Zgodnie z aktualnymi wykazami podręczników dla pierwszoklasistów, zamieszczonymi na stronach internetowych bułgarskiego oraz polskiego Minister- 
stwa Edukacji Narodowej, wybrałam do porównania następujące elementarze: Lokomotywa. 1 [Dobrowolska 2017] і Буквар за 1. клас [Попов 2017]. W tym miejscu warto zaznaczyć, iż zgodnie z ustawami wydanymi przez ministerstwa obu krajów, dzieci, które zaczynają edukację w klasie pierwszej szkoły podstawowej, muszą mieć ukończone 6 lub 7 lat. Zatem w obydwóch przypadkach mamy do czynienia z podobną grupą wiekową odbiorców.

Systemy nauczania nieco różnią się od siebie. W Polsce edukacja w szkole podstawowej dzieli się na dwa etapy. Pierwszy etap, to edukacja wczesnoszkolna. Odbywa się ona na przestrzeni trzech lat. Natomiast drugi etap obejmuje klasy od IV do VIII. Znaczącą rolę odgrywa klasa pierwsza, ponieważ stanowi przejście między przedszkolem a szkołą. Przygotowuje dzieci do wejścia w świat wiedzy, uczy zasad życia w społeczeństwie oraz pracy w grupach. Wiedza na dane tematy w klasie pierwszej jest wykorzystywana i poszerzana w kolejnych klasach. Zajęcia w ramach edukacji wczesnoszkolnej mają charakter zintegrowany, co oznacza, że nie ma podziału na przedmioty ${ }^{1}$. Dlatego też obowiązuje jeden podręcznik, na podstawie którego przeprowadzane są zajęcia. Lekcje prowadzone są przez jednego nauczyciela, który również pełni rolę wychowawcy. To on ustala przebieg zajęć i wyznacza czas na wykonanie konkretnych zadań, na przykład: ćwiczenia z matematyki, czytanie lub pisanie. Jedynie niektóre zajęcia (wychowanie fizyczne, język obcy) przeprowadzane są oddzielnie przez nauczycieli posiadających odpowiednie kwalifikacje.

Tymczasem w Bułgarii edukacja podstawowa dzieli się na następujące dwa etapy: podstawowy (начално училище) w klasach o I do IV i przedgimnazjalny (основно училище) w klasach od V do VII [Zashev]. W odróżnieniu od polskiego systemu edukacji zajęcia dzielone są na następujące przedmioty: język bułgarski i literatura, matematyka, język angielski, wychowanie fizyczne, muzyka, plastyka oraz wiedza o świecie ${ }^{2}$. Do każdego z tych przedmiotów przygotowane są osobne podręczniki. Największą rolę odgrywa język bułgarski i literatura. W wymiarze tygodniowym najwięcej jednostek lekcyjnych poświęconych jest temu przedmiotowi. W klasie pierwszej dzieci nabywają umiejętności pisania i czytania oraz sprawnego komunikowania się w rodzimym języku³. Program nauczania z języka

${ }^{1}$ Edukacja w klasach I-III szkoły podstawowej realizowana jest w formie kształcenia zintegrowanego. Ze względu na prawidłowości rozwoju umysłowego dzieci, treści nauczania powinny narastać i rozszerzać się w układzie spiralnym, tzn., że w każdym następnym roku edukacji wiadomości i umiejętności nabyte przez ucznia mają być powtarzane i pogłębiane, a potem rozszerzane. Podstawa programowa kształcenia ogólnego dla szkół podstawowych [Fragment załącznika nr 2 rozporządzenia], str. 23 pkt 5. https://men.gov.pl/wp-content/uploads/2011/02/1c.pdf [dostęp: 3.10.2018].

2 Дьржавните образователни изисквания за обучението по български език и литература в първи клас са отразени в учебната програма за училищата в България по предмета (Програма БЕЛ).

${ }^{3}$ Учебният предмет български език и литература в началния етап на основната образователна степен има комплексен характер и поставя основата на системното изучаване на българския език и на литературата в следващия образователен етап. В центъра на двете предметни области са комуникативноречевите умения, чрез които се гарантира практическата насоченост на обучението. Обучението по български език и литература в началния етап на основна- 
bułgarskiego i literatury obejmuje tematyką różne dzieciny, dzięki czemu zdolności poznawcze dzieci są poszerzane ${ }^{4}$.

Przechodząc do analizy elementarzy w pierwszej kolejności warto zwrócić uwagę na ich budowę i wygląd. Bułgarski podręcznik składa się z jednej, spójnej części. Uwzględnione $\mathrm{w}$ nim zagadnienia poświęcone są przede wszystkim nauce liter, dzielenia wyrazów na sylaby oraz rozpoznawaniu głosek. Pojawiają się proste zadania bazujące na słownictwie, na przykład: dopasowywanie liter do odpowiednich luk tak, aby powstało prawidłowo zapisane słowo oraz uzupełnianie zdań właściwymi wyrazami. Szata graficzna w tym elementarzu ma charakter rysunkowy. Jest bardzo kolorowa i bazuje na podstawowych skojarzeniach, takich jak: miś wyjadający miód z ula, pies przynoszący kapcie. Zabiegiem, który nadaje grafikom dziecięcy charakter jest personifikacja większości przedmiotów, roślin oraz zwierząt. Posiadają one typowe cechy dla człowieka: rysy twarzy, sposób zachowania się oraz styl ubierania. Przykładem jest ilustracja przedstawiająca zwierzęta będące na wakacjach. Siedzą przy stolikach, rozmawiają, jedzą kolorowe desery i piją soki. Jedynym zdjęciem, które możemy odnaleźć w elementarzu jest fotografia Baby Tonki. Postać ta ściśle związana jest z historią Bułgarii. Poza tym zostały zamieszczone ikony: świętych Cyryla i Metodego oraz Jezusa Chrystusa.

Polski podręcznik składa się z dwóch części. Pory roku są głównym kryterium segmentacji elementarza. Tematyka nawiązuje do rocznego cyklu życia. Pojawiają się zjawiska atmosferyczne i ważne święta charakterystyczne dla danego okresu. Oprócz zagadnień ściśle związanych z nauką liter, dzieci zdobywają wiedzę o świecie. Poruszane są aspekty kulturowe, społeczne oraz przyrodnicze. Pojawiają się także instrukcje do wykonania prostych prac plastycznych. Szata graficzna elementarza jest bardziej rozbudowana w porównaniu z bułgarskim odpowiednikiem. Opiera się na rysunkach, zdjęciach oraz grafikach komputerowych. Są one bardzo szczegółowe, złożone z wielu elementów. Zdjęcia, które zostały zamieszczone, przedstawiają głównie różnego rodzaju rośliny, zwierzęta, przedmioty oraz ludzi.

та образователна степен е насочено към постигане на базовото равнище на ключовата компетентност, свързана с комуникацията на български език, и към реализиране на междупредметни връзки и комплекс от дейности, подчинени на съвременните ключови компетентности. Целите на обучението по български език и литература в първи клас се свързват с началното ограмотяване, което е ключова предпоставка за осъществяването на единния езиков и литературен образователен процес, за интелектуалното и речевото развитие на учениците. Усвояват се ефективни „инструменти” за общуване, каквито са техниките за четене и писане, в единство с разбирането на прочетеното и написаното. Учениците се въвеждат в езиковата и речевата действителност, за да овладяват умения за разпознаване и използване на основните езикови и комуникативни единици - текст, изречение, дума, сричка, звук. Учебна програма по български език и литература за I клас (общообразователна подготовка), [dostęp: 3.10.2018] https://www.mon.bg/bg/1699.

${ }^{4}$ Учебната програма по български език и литература за първи клас представя учебното съдържание тематично чрез очакваните резултати от обучението по всяка тема и свързаните с нея понятия.// Учебна програма по български език и литература за I клас (общообразователна подготовка), [dostęp: 3.10.2018] https://www.mon.bg/bg/1699. 
Analizując poszczególne grafiki obu elementarzy można zauważyć, że w bułgarskim podręczniku znacznie większy nacisk kładziony jest na relacje rodzinne. Pojawia się wiele rysunków ukazujących matkę z dziećmi podczas wykonywania czynności związanych z życiem codziennym, na przykład: robienie zakupów, pomoc w kąpieli lub układanie do snu. Możemy również zobaczyć ilustrację przedstawiającą typowe, rodzinne spotkanie. Dziadkowie siedzą przy stole razem z rodzicami, natomiast dzieci w dalszej części pokoju rozmawiają. Pojawiają się także rysunki przedstawiające ojca opiekującego się dziećmi oraz bawiącego się z nimi, a także wnuki rozmawiające $\mathrm{z}$ dziadkami i pomagające im. Z kolei na innych ilustracjach przedstawione są wartości takie, jak: współpraca, koleżeństwo. Starsze dzieci pomagają młodszym, wspólnie bawią się, grają w piłkę. Systematycznie na ilustracjach w bułgarskim elementarzu powtarza się temat związany z muzyką. Między innymi nakreślone zostały sylwetki dzieci śpiewających i tańczących oraz grupa zwierząt grająca na instrumentach muzycznych. Poza tym możemy zobaczyć chłopca słuchającego muzykę przez słuchawki. Na szczególną uwagę zasługują postaci śpiewających kobiet, które są ubrane w stroje ludowe. Pojawiają się również różnokolorowe nuty. Najczęściej występującymi instrumentami muzycznymi są gitara (6 razy) oraz bęben (4 razy).

W elementarzu polskim także znajdują się grafiki nawiązujące do relacji rodzinnych, koleżeńskich, jednak nie są one aż tak częste. Dominują ilustracje związane $\mathrm{z}$ technologią, życiem społecznym, poruszaniem się w przestrzeni publicznej oraz geografią. Na potwierdzenie wyżej wymienionych stwierdzeń przytoczę kilka przykładów. Jednym z nich jest grafika przedstawiająca sytuację, gdzie nauczyciel pokazuje uczniom poszczególne elementy budowy komputera. Jeśli chodzi o przestrzeń publiczną, kilkukrotnie pojawiają się grafiki ukazujące plan budowy miasta z wyróżnieniem takich budynków, jak: ratusz, filharmonia, kino, teatr, supermarket. Poruszona jest również kwestia bezpieczeństwa na drodze oraz zachowania się podczas wypadku samochodowego. Ponadto pod koniec drugiej części elementarza została nakreślona kwestia związana z geografią polski, Europy i świata. Pojawiają się różnego rodzaju mapy. Jedna z nich uwzględnia administracyjny podział krajów należących do Unii Europejskiej. Na następnej zostały podkreślone państwa, które sąsiadują z Polską. W obu przypadkach dodatkowo zamieszczono flagi poszczególnych państw. Kilkukrotnie pojawia się mapa Polski z zaznaczonymi charakterystycznymi uwarunkowaniami geograficznymi. Zamieszczone zostały także zdjęcia najsłynniejszych europejskich zabytków. Dzięki temu dzieci mają okazję zapoznać się ze stolicami krajów, takich jak: Francja, Grecja, Włochy, Wielka Brytania, Czechy, Niemcy, Austria, Belgia. W sposób kolorowy i obrazowy przedstawiono mapę świata z podziałem na kontynenty. Na różnych obszarach pojawiają się postaci w strojach typowych dla danego regionu.

Kontynuując temat urbanizacji, warto zwrócić uwagę na uwzględnione w elementarzach miasta. W podręczniku bułgarskim na ilustracjach możemy rozpoznać Sofię i Ruse. Natomiast w polskim zamieszczono fotografie Warszawy, Krakowa i Gdańska. 
Cechą wspólną dla obydwu podręczników jest motyw lokomotywy. W bułgarskim podręczniku pojawia się ona w każdym rozdziale, w którym dziecko poznaje nową literę. Ciągnie ona za sobą cztery wagony. W każdym z nich znajduje się ta sama litera zapisana inną czcionką oraz grafika przedmiotu, który stanowi pomoc w nauce nowej litery. Natomiast w polskim elementarzu występuje w nazwie oraz w miejscach, gdzie postawione są pytania odnoszące się do danego tematu lub ilustracji.

Możemy odnaleźć również inne cechy wspólne dla obu podręczników. Ilustracje ukazujące dzieci bawiące się i spacerujące na świeżym powietrzu oraz jedzące zdrowe posiłki, złożone $\mathrm{z}$ warzyw i owoców, promowany jest zdrowy tryb życia. Prócz tego została poruszona kwestia symboli narodowych. Zarówno w jednym, jak i w drugim elementarzu kilkukrotnie widoczne są flagi narodowe. W obydwu książkach możemy dostrzec dzieci ubrane w stroje galowe, trzymające flagę. W bułgarskim podręczniku pojawia się ona także w miejscu, gdzie poznawana jest litera „M”, pod hasłem „знаме”. W polskim podręczniku dodatkowo zamieszczone są godło oraz fragment hymnu. Co więcej w obu podręcznikach występuje postać pełniąca funkcję przewodnika po książce. W elementarzu bułgarskim jest to czarodziej. Wskazuje na to jego strój oraz gesty, które wykonuje. Można go zauważyć przy każdym temacie związanym z poznawaniem nowej litery. W polskim taką rolę odgrywa papuga. W większości przypadków obok niej pojawia się chmurka z wypowiedzią. Występują także nawiązania do tradycyjnych dań. W bułgarskim podręczniku jest to banica, natomiast w polskim - pierogi i oscypek.

Warto również przyjrzeć się bliżej kwestii związanej z pojawiającymi się w elementarzach przedmiotami, zwierzętami, roślinami oraz innymi charakterystycznymi zjawiskami. Przeprowadziłam szczegółowy spis wszystkich wyżej wymienionych kategorii, aby zbadać ich frekwencję w poszczególnych podręcznikach. Najczęściej występującymi zwierzętami w elementarzu bułgarskim są: pies -9 , bocian biały -7 , wróbel -6 . Jeśli chodzi o kwiaty, najpopularniejszym jest mak, gdyż możemy go rozpoznać na czterech grafikach. Natomiast emblematyczna dla kraju róża występuje tylko raz. Przyglądając się ilustracjom przedstawiającym krajobraz, możemy zaobserwować charakterystyczne elementy ukształtowania terenu Bułgarii. Siedem razy pojawiają się góry, oprócz tego dwa razy lasy i raz morze z piaszczystą plażą. Wszystkim tym grafikom towarzyszy słońce, które zawsze ma namalowany uśmiech. Grafiki przedstawiające niekorzystne warunki atmosferyczne są niewielkie i zazwyczaj ulokowane na rogu strony.

W elementarzu polskim zwierzęciem, które pojawia się najczęściej jest czerwona papuga ara (38 razy). Następnie na równi plasują się pies i kot (25 razy).

W obu elementarzach dzieci poznają alfabet oraz różne sposoby zapisywania poszczególnych liter, uczą się dzielić słowa na sylaby, a także rozróżniać samogłoski od spółgłosek. Pod każdym rozdziałem występują charakterystyczne imiona zawierające aktualnie poznawaną literą oraz słowa, które są ukazywane za pomocą grafik. Dodatkowo pojawiają się teksty o różnej tematyce i długości. 
Powyżej wymienione elementy łączą oba elementarze, jednak przyglądając się im bliżej, możemy dostrzec rozbieżności. Po pierwsze pod każdym rozdziałem w podręczniku bułgarskim pojawia się duża ilość słów, które zawierają nowo poznawaną literę. Dziecko ma za zadanie wpisać odpowiednie litery w kratki znajdujące się pod grafikami, aby powstały poprawnie zapisane wyrazy. Okienka z samogłoskami zaznaczone są na czerwono, a ze spółgłoskami na niebiesko. Dodatkowo na dwa sposoby ukazany jest podział słów na sylaby. Miejsca, gdzie dziecko wpisuje wyrazy oddzielane są grubą, pionową linią. Natomiast w pozostałych przypadkach łukiem pod słowami. Co więcej na dole każdej strony znajduje się spis wszystkich liter alfabetu. Przedstawiony został za pomocą niewielkich karteczek, ustawionych w szeregu, trzymanych przez dzieci i zwierzęta. Kolejność poznawania liter nie jest alfabetyczna, ale układ graficzny pozwala uczniom na zaobserwowanie pozycji danej litery w alfabecie. Na początku podręcznika nad alfabetem pojawia się ikona świętych Cyryla i Metodego. Zjawisko to świadczy o dużym przywiązaniu Bułgarów do historii i tradycji piśmiennictwa. Natomiast jeśli chodzi o sam alfabet, wyszczególnione zostały w nim następujące parametry: małe, duże litery, forma pisana i drukowana. Teksty, które pojawiają się pod każdym rozdziałem są krótkie i w większości przypadków rymowane.

W polskim elementarzu zastosowano podobne strategie, na przykład jeśli chodzi o kolorystyczne oznaczenie głosek oraz dzielenie wyrazów na sylaby za pomocą łuku. Przy każdej nowo poznanej literze pojawia się słowo przewodnie, które ukazane jest za pomocą grafiki oraz zapisywane na trzy sposoby (drukowanymi literami z podziałem na głoski oraz sylaby, drukowanymi bez podziałów i w formie pisanej). Teksty, które pojawia się pod rozdziałami są dłuższe i bardziej złożone niż te w bułgarskim podręczniku. Jedynie na początku elementarza występują grafiki obrazujące słowa, które są podawane przy okazji zapoznawania się z nowymi literami. W dalszej części zrezygnowano z tej strategii i pojawiają się tylko szereg wyrazów. Spis wszystkich liter w kolejności alfabetycznej przedstawiony jest trzy razy dopiero na końcu drugiej części elementarza. Pierwszy raz wraz z ilustracjami, z którymi występowały poszczególne litery, następnie cały alfabet razem $z$ polskimi znakami. Trzeci raz na brzegu strony bez uwzględnienia polskich znaków.

Dzięki dokładnej analizie różnych aspektów związanych z szatą graficzną poszczególnych elementarzy, można dostrzec w niektórych miejscach wpływ sposobu postrzegania świata przez społeczeństwo danego kraju. Już od najmłodszych lat u dzieci budowane są skojarzenia, które w sposób pośredni wpływają na ich świadomość i budowanie własnej tożsamości. Elementarz bułgarski kładzie większy nacisk na stosunki rodzinno-koleżeńskie, a także tradycje ludowe. Oprócz tego w sposób przejrzysty i przystępny dla dziecka stopniowo wprowadza zagadnienia związane z poznawaniem nowych liter oraz leksyki. Natomiast polski podręcznik przede wszystkim skupia się na aspektach społecznych, ukazaniu kraju na tle Europy oraz prezentuje zagadnienia związane z nowymi technologiami. Treści związane z nauką liter zaprezentowane są w sposób przejrzysty, jednak w porównaniu do pozostałych tematów stanowią niewielką część podręcznika. Pomimo aspektów, 
które odróżniają te dwa elementarze, możemy zauważyć również cechy wspólne wynikające $\mathrm{z}$ uniwersalnego sposobu przekazywania wiedzy dzieciom w edukacji wczesnoszkolnej oraz z przynależności obu krajów do kultury słowiańskiej.

Podczas pracy na wybranych podręcznikach, napotkałam się na trudności związane z dysproporcją między elementarzami. Objętościowo podręcznik polski jest dwa razy większy, co za tym idzie zawiera dużo więcej materiału. Jednak treści zawarte w elementarzu bułgarskim pozwoliły na to, by w sposób rzeczowy dokonać analizy porównawczej szaty graficznej. Kwestia związana z zestawieniem różnych typów elementarzy jest obszerna i warta dalszego poznania.

\section{Bibliografia}

Adrjan B., Kalinowska A. (2018), Cyfrowy świat w podręczniku dla klasy pierwszej szkoty podstawowej - analiza treści, „Problemy wczesnej edukacji / Issues in early education”, nr 2 (41).

Dobrowolska M., red. (2017), Lokomotywa 1. Elementarz. Część 1, Gdańskie Wydawnictwo Oświatowe, Gdańsk

Program MEN: Podstawa programowa kształcenia ogólnego dla szkót podstawowych [Fragment załącznika nr 2 rozporządzenia], str. 23 pkt 5., https://men.gov.pl/wp-content/uploads/ 2011/ 02/1c.pdf [dostęp: 3.10.2018].

Zalewska E. (2013), Obraz świata w podręcznikach szkolnych do klas początkowych, Wydawnictwo Uniwersytetu Gdańskiego, Gdańsk.

Zashev S., Organizacja systemu edukacji w Bułgarii, http://cdn.leszno.pl/files/pbp/2016/10/13.pdf [dostęp: 3.10.2018].

Йорданова, Д. Контент анализ на учебните програми по български език с оглед на обучението по правоговор и правопис в началните класове. // Педагогически алманах. Научно списание (ISSN: 1310-358X) 2012, nr 1 (20), s. 65-82, http://journals.uni-vt.bg/almanac/bul/ vol20/iss1/6 [dostęp: 3.10.2018].

Попов В. (2017), Буквар за първи клас. Просвета Азбуки, София.

Програма БЕЛ: Учебна програма по български език и литература за I клас (Общообразователна подготовка), www.mon.bg/upload/12295/BEL_1kl.pdf [dostęp: 3.10.2018].

Justyna Fafara

\section{THROUGH CHILDREN'S EYES, OR ON THE GRAPHIC LAYOUT OF CONTEMPORARY POLISH AND BULGARIAN ALPHABET BOOKS FOR FIRST GRADE}

(Summary)

The paper examines the graphic and illustrative elements in contemporary Polish and Bulgarian alphabet books. The comparative approach reveals basic similarities and significant differences between the selected textbooks concerning the preferred thematic fields in the primary education process in both countries. The analysis allows to differentiate the prevailing motives and values depicted in the textbooks (such as family and social relations, national symbols, modern technologies), the strategies of presenting the letters of the alphabet, the leading book characters, etc.

Key words: alphabet book, ABC-book, primer, textbook graphic design, illustration, alphabet learning, Polish textbook, Bulgarian textbook, primary education 